\title{
Immunomodulatory and Antioxidant Activity of Green Grass Jelly Leaf Extract (Cyclea barbata Miers.) In Vitro
}

\author{
Mustafid Rasyiid*, Rendi Mahadi, Krisnanda Surya Dharma, Lindia Anggraini, Rahma Nurdiyanti \\ and Tri Rini Nuringtyas \\ Faculty of Biology, Universitas Gadjah Mada, Indonesia \\ *Email: mustafid.rasyiid@gmail.com
}

\begin{abstract}
Green grass jelly (Cyclea barbata Miers.) is known for its benefit to human health especially in supporting body's immune system and wellness. This research aimed to determine immunomodulatory and antioxidant activity of green grass jelly leaf extracts in vitro. Old leaves were collected as sample then dried and ground to powder. The extraction was done with sohxletation using three different solvents, chloroform, ethyl acetate, and ethanol. The immunomodulatory activity was evaluated by treating the crude extracts at concentrations of 50,100 , and $500 \mu \mathrm{g} / \mathrm{mL}$ on macrophages of rat in vitro. The treated macrophage was then challenged for their phagocytic activity to latex beads. The antioxidant activity was done using 1,1diphenil-2-picrilhydrazil (DPPH) with spectrophotometry technique. All treatments were done with three replicates. Detection of the bioactive groups of the extracts was done by Thin Layer Chromatography (TLC). The results showed that ethyl acetate extract has the highest phagocytic activity followed with chloroform extract and ethanol extract, respectively. Optimum concentration was reached at $100 \mu \mathrm{g} / \mathrm{mL}$ of ethyl acetat extract. The ethyl acetate extract was also the extract with the highest antioxidant activity index 7.7 followed by both extracts of chloroform and ethanol with similar index value of 6.25 and 6.3 , respectively. The ethyl acetate extract contained phenolics, flavonoids, tannins, and terpenoids.
\end{abstract}

Keywords: Cyclea barbata Miers., green grass jelly, antioxidant, immunomodulator, DPPH

\section{INTRODUCTION}

A decrease in the body's immune system can be caused by increase dense and stressful lifestyle, low environmental quality, and erratic of weather change. These all may exert the susceptibility of the body to disease and at the end can reduce the quality of human life. Improving the body's immune system can be obtained in various ways, one of them with immunomodulators or antioxidant supplements. Antioxidants are compounds that can defeat the negative effects of oxidants in the body to donate one of its electrons to the oxidant compounds that inhibited the activity of the oxidant. Oxidant compounds presenting in the form of free radicals or other reactive compounds, can cause an intensive damages in the body due to the low antioxidant condition make the body unable to compensate for the oxidative reactivity of the compound [1]. The decline of antioxidants in the body is directly proportional to the increase in diseases. Hence, supplementation with antioxidants may slow the progression of the disease [2].

Immunomodulatory or imunostimulant, is a substance capable of stimulating leukocyte cells, especially macrophages to form the body's immune system and acts as a suppressant of the overactive immune reaction and return it back to the normal body condition. Imunostimulant provides independently a response on the modifying nonspecific defense system or when combined with other substances. Nonspecific defense system is very important for the prevention of pathogenic microorganisms in multicellular animals [3].

Both immunodulatory compounds and antioxidant can be derived from raw materials such as synthetic or natural immunostimulant. One of the Indonesia's plant Cyclea barbata Miers or green grass jelly plant has been widely used locally to support the fitness of the body and increase immunity. This indicates the potential of green grass jelly leaves as an immunomodulator and natural antioxidants. Previous study reported that the leaves contain active chemical compounds including chlorophyll, alkaloids, terandin, dimethyl tetrandin, polyphenols, saponin, and flavonoids [4]. However, no study has reported further bioactivity of these leaves extracts which underlie the traditional use of the plant in society.

In this regards, it is necessary to do research on immunomodulatory and antioxidant activity in leaf extracts of green grass jelly, as an effort to increase the body's immune system as well as natural antioxidants for the body. The leaves are green grass jelly can be processed into nutritious drinks, natural supplements, or herbal medicines which can play a role in increasing endurance and body health.

This research aims to determine the immunomodulatory and antioxidant activity of leaf extracts of green grass jelly (Cyclea barbata Miers.) In vitro. In this research, akitivitas test and phagocytic capacity, antioxidant activity index analysis, as well as the content of bioactive compounds in green grass jelly leaf extract.

\section{RESEARCH METHOD}

\section{Sample Preparation}

Leaves green grass jelly (Cyclea barbata Miers.) were collected and washed with water, sorted, and air dried. To complete the drying, the leaves were put in the oven at a temperature of $40-50{ }^{\circ} \mathrm{C}$ until reaching their constant weight, and powdered using blender.

\section{Extraction Leaves Green Grass Jelly}

Extraction was done by a serial soxhletation method using three different solvents including chloroform, ethyl 
acetate, and ethanol. An amount of $10 \mathrm{~g}$ dried powder sample was wrapped with filter paper, then placed into extractor tube that has been assembled into a soxhlet device. The extraction consider complete when the solvent turned to clear. The serial soxhletation was done from the most non polar solvent, chloroform followed by ethyl acetate and ethanol, respectively. The crude extracts were dried using rotary evaporator at $40{ }^{\circ} \mathrm{C}$.

\section{Macrophage Cell Suspension Preparation}

Rat was euthanized using ketamine and further received a neck dislocation. Rat placed in the supine position and the abdomen subsequently cleaned using alcohol $70 \%$. Surgery was performed by opening the skin on the abdomen. $15 \mathrm{ml}$ of cold RPMI 1640 medium was injected to the intra peritoneal using syringe and left for 3 min with occasional shaking using fingers and helped the peritoneal macrophage cells separated from the tissue. Peritonial fluid was aspirated using the syringe followed by centrifugation at $1200 \mathrm{rpm}$ at $4{ }^{\circ} \mathrm{C}$ for $10 \mathrm{~min}$. The supernatant was discarded and replaced with $1 \mathrm{ml}$ complete RPMI medium (containing $10 \%$ FBS) in pellets. A mixture containing of $50 \mu \mathrm{L}$ giemsa and $10 \mu \mathrm{L}$ cell suspension was dropped into haemocytometer and subjected for cell density determination. The cell suspension was diluted to reach a density of $2,5 \times 10^{6} / \mathrm{mL}$ using complete RPMI medium. Subsequently, the cell suspension was cultured in 24-well microplate which previously mounted with coverslips. Each well contained $200 \mu \mathrm{L}$ (equal to $5 \times 10^{5}$ cells) of the cell suspension. The plates were incubated at $37{ }^{\circ} \mathrm{C}$ for $30 \mathrm{~min}$, with $5 \% \mathrm{CO}_{2}$. Medium was replaced after overnight incubation.

\section{Preparation Of Test Extracts}

Each extract was weighed $10 \mathrm{mg}$ and dissolved in $1000 \mu \mathrm{L}$ of DMSO and vortex vigorously. This extract was diluted in the Laminar Air Flow (LAF) in order to reach a final concentration of $50 \mu \mathrm{g}, 100 \mu \mathrm{g}$, and $500 \mu \mathrm{g}$. The complete medium was used to replace extract as the negative controls while Imboost $₫$ was used as immunomodulator standardized supplement.

\section{Immunomodulators Test}

Phagocytic activity and phagocytic capacity were performed in vitro using latex beads that suspended in
PBS. Each well containing overnight cultured macrophages was added with $200 \mu \mathrm{L}$ of latex suspension, and incubated again at $37{ }^{\circ} \mathrm{C}$ for 60 min with $5 \% \mathrm{CO}_{2}$. After finished the incubation, the cells were washed with PBS for three times to remove the left latex, followed by drying and fixation with $100 \mu \mathrm{L}$ abs methanol for $30 \mathrm{~s}$, for $10 \mathrm{~min}$. At the end of incubation, $50 \mu \mathrm{L}$ of giemsa was added. Then, prior to coverslip removal, the cells were washed with distilled water for three times. The coverslip then was observed under light microscope with $400 \mathrm{x}$ magnification.

\section{Determination Of Phagocytic Activity And Phagocytic Capacity}

Both of phagocytic capacity and phagocytic activity (SFA) was calculated using these following equations [5].

$$
\begin{gathered}
\text { phagocytic activity }=\frac{\text { amount of active macrophages }}{\text { total of } 100 \text { macrophages counted }} \times 100 \% \\
\text { Phagocytic capacity }=\frac{\text { amount of latex that phagocites }}{\text { amount of } 50 \text { active macrophages }}
\end{gathered}
$$

\section{DPPH assay}

The $0.1 \mathrm{mM}$ DPPH solution was prepared in methanol. The standard curve was prepared using Vitamin $\mathrm{C}$ in a serial concentration of $0.2,0.4,0.8,1.6$, and 3.2 $\mathrm{mg} / \mathrm{ml}$. The stock solution of each crude extracts were prepared by dissolving $50 \mathrm{mg}$ of dried crude extract in 50 $\mathrm{ml}$ methanol. These stock were used for a serial concentration from 2.5-160 ppm. The measurement was done by mixing $2 \mathrm{ml}$ of DPPH solution with $1 \mathrm{ml}$ sample extract in the cuvettes and incubated for $30 \mathrm{~min}$ in the dark. The absorbance of the solution was recorded at 517 $\mathrm{nm}$ using spectrophotometer. The antioxidant activity index was calculated using this equation [6].

$$
\text { Antioxidant Activity Index }(A A I)=\frac{D P P H \text { concentration }(p p m)}{\text { IC50 value }(p p m)}
$$

\section{Secondary Metabolites Detection}

Identification of the group of bioactive compounds was done using Thin Layer Chromatography (TLC) for the separation of the compounds from crude extract and followed by spraying detection reagents

TABLE 1.

DETECTION REAGENT FOR IDENTIFICATION OF BIOACTIVE COMPOUNDS [7]

\begin{tabular}{ccc}
\hline Detection reagent & Compound groups & Positive color \\
\hline Anisaldehid sulfuric & Terpenoids & Purplish red \\
Citroborat & Flavonoids & Yellow \\
$\mathrm{FeCl} 3$ & Phenolics & Dark green-black \\
$\mathrm{FeCl} 3$ & Tannins & Green-black \\
Dragendorf & Alkaloids & Orange \\
\hline
\end{tabular}

Identification of the compound above using different mobile phase. For the chloroform and the ethyl acetate extracts used a mixture of solvents $n$-hexane: ethyl acetate $(3: 7)$. While the ethanol extract with chloroform eluent: ethyl acetate: toluene $(2$ : $6: 2)$. 


\section{RESULTS AND DISCUSSION}

The crude extracts obtained from the three different solvents had comparable weight as much as $12.9 \mathrm{mg}$ for ethanol extract, ethyl acetate extract $13.84 \mathrm{mg}$, and 12.18 mg extract of chloroform. The ethyl acetate extract observed a relative higher portion than others indicating that the leaves green grass jelly contains many compounds that are semipolar.

TABLE 2.

BIOACTIVE COMPOUND OF CHLOROFORM, ETHYL ACETATE AND ETHANOL EXTRACTS OF GREEN GRASS JELLY (Cyclea barbata Miers.) LEAVES

\begin{tabular}{|c|c|c|c|c|c|c|c|c|c|c|}
\hline \multirow{3}{*}{ Extract } & \multicolumn{10}{|c|}{ Bioactive Compound } \\
\hline & \multicolumn{2}{|c|}{ Terpenoids } & \multicolumn{2}{|c|}{ Flavonoids } & \multicolumn{2}{|c|}{ Tannins } & \multicolumn{2}{|c|}{ Phenolics } & \multicolumn{2}{|c|}{ Alkaloids } \\
\hline & n spot & $\mathrm{Rf}$ & n spot & Rf & $\mathrm{n}$ spot & Rf & n spot & Rf & n spot & $\mathrm{Rf}$ \\
\hline Chloroform & 1 & 0,925 & 1 & 0,425 & 1 & 0,762 & 1 & 0,85 & - & - \\
\hline Ethyl acetate & 1 & 0,925 & 1 & 0,412 & 1 & 0,7 & 1 & 0,775 & - & - \\
\hline Ethanol & 1 & 0,925 & 1 & 0,75 & - & - & - & - & - & - \\
\hline
\end{tabular}

The results of bioactive compounds detection indicated that the chloroform and the ethyl acetate extracts contained a potentially immunomodulator and antioxidant compounds such as terpenoids, flavonoids, tannins and phenolics. While the ethanol extract contains two bioactive compounds are terpenoids and flavonoids (Table 2).

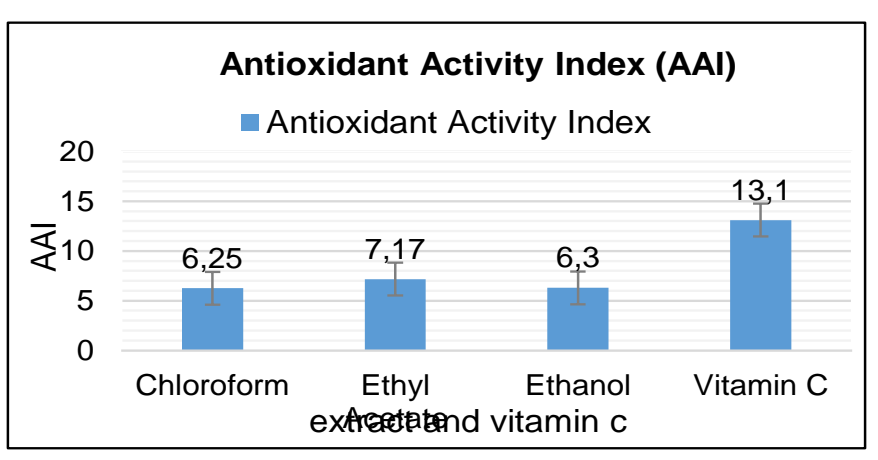

Figure 1. Antioxidant activity index values of extract and vitamin $\mathrm{C}$ (control)

Green grass jelly extracts were known to have very strong antioxidant activity based on the classified value of Antioxidant Activity Index (AAI). Classified natural extract had antioxidant activity weakened if the value AAI $<0.5$, moderated activity if the AAI $0.5-1$, stronged if the value AAI 1-2, and if the value of AAI $>2$ that includes a very strong antioxidant [8].

In Figure 1. was known that the AAI each extract greater than 2, so that it could be classified as a very strong antioxidant. The highest antioxidant activity of leaf green grass jelly was the ethyl acetate extract with value of 7.17, followed AAI ethanol extract 6.3, and 6.25 while the chloroform extract of vitamin $\mathrm{C}$ were used as positive control (+) has a value of 13.1 AAI.

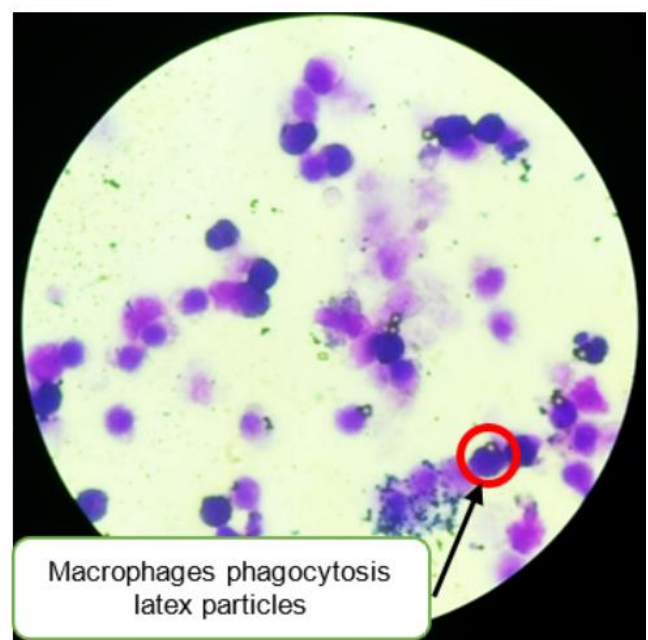

Figure 2. Macrophages phagocytosis latex-treated leaf extract of green grass jelly (red circle), with magnification 40 times

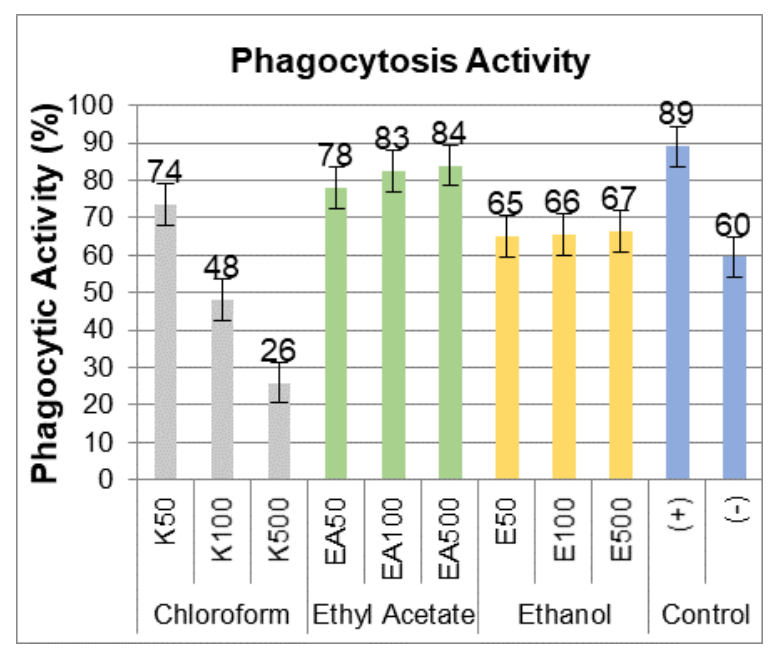

Figure 3. Phagocytosis activities three green grass jelly leaf extract, positive control imboost ${ }^{\circledR}$. 


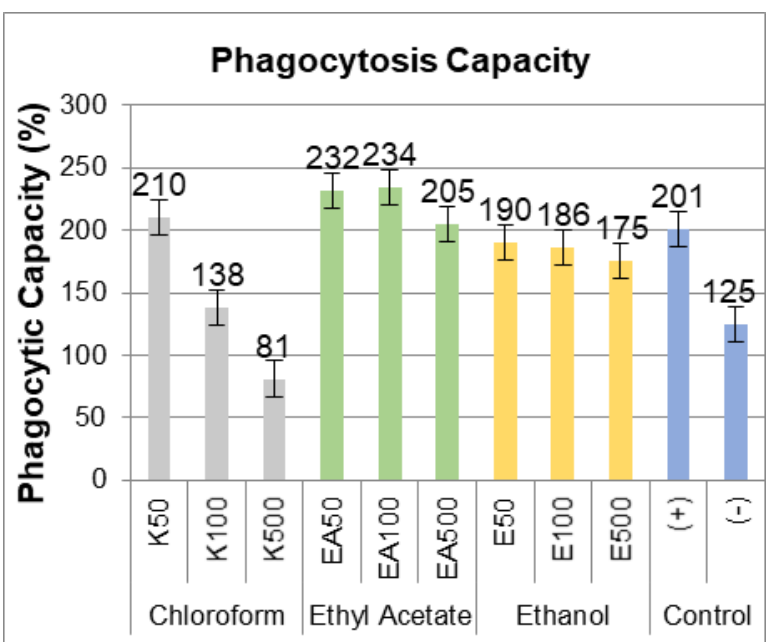

Figure 4. Phagocytosis capacity three green grass jelly leaf extract, positive control imboost $®$.

The results showed that administration of three green grass jelly leaf extract in cell culture can increase the activity of macrophages and macrophage phagocytic capacity. From Figure 3 and 4. known that the ratio value of the activity and the phagocytic capacity of the three extract approach positive control $(+)$ treated Imboost ${ }^{\circ}$. The average concentration of the ethyl acetate extract phagocytic capacity indicate even higher than the control value (+). Treatment with ethyl acetate extracts of green grass jelly leaf causes an increase in phagocytic activity and the phagocytic capacity of macrophage cells highest compared to other extracts. Ethyl acetate extracts of green grass jelly leaves at a concentration of $100 \mathrm{pg} / \mathrm{ml}$ was optimal concentration in enhancing phagocytic activity and the phagocytic capacity of macrophage cells. Unknown ethyl acetate extract at a concentration of $100 \mathrm{pg} / \mathrm{ml}$ had a value of $83 \%$ phagocytic activity and phagocytic capacity amounted to $234 \%$. In general, the value of the phagocytic activity of phagocytic capacity and highest in the ethyl acetate extract, followed ethanol extract, and then chloroform extract.

\section{CONCLUSION}

The ethyl acetate extract of green grass jelly leaf extract (Cyclea barbata Miers.) has a high immunomodulatory activity and antioxidant activity. The ethyl acetate extract of green grass jelly leaves contained terpenoids, flavonoids, tannins, and phenolic. The ethyl acetate extract has antioxidant activity index value (AAI), phagocytic activity, and the highest phagocytic capacity compared to other extracts with optimal concentration was $100 \mathrm{ug} / \mathrm{ml}$. Further study should be prepared using in vivo approach to validate this report.

\section{REFERENCES}

[1] Louis, S. G. and Alfred, G. Autakoid: Terapi Obat untuk Inflamasi. In: Joel G. Hardman, Lee E Limbird. 2007. Dasar Farmakologi Terapi, Edisi 10. Alih bahasa oleh Amalia Hanif. Jakarta: Penerbit Buku Kedokteran EGC.

[2] Nursalam dan Kurniati N. D. 2007. Asuhan Keperawatan pada Pasien Terinveksi HIV/AIDS. Jakarta: Penerbit Salemba Medika.

[3] Paulsen, B. S. 2000. Bioactive Charbohydrate Polymers. Netherland: Kluwer Academic Publishers.

[4] Shodiq, A. M. 2012. Uji Aktivitas Antioksidan Ekstrak dan Fraksi Daun Cincau Hijau Rambat (Cyclea Barbata Miers.) dan Identifikasi Golongan Senyawa dari Fraksi Yang Paling Aktif (Skripsi). Depok: Fakultas Matematika dan Ilmu Pengetahuan Alam Program Sarjana Farmasi, Universitas Indonesia.

[5] Jensch-Junior, B.E., Pressinotil, N., Borges, J.C.S. \& Cunha Da Silva, J.R.M. 2006. Characterization of Macrophage Phagocytosis of the Tropical Fish Prochiladus scrofa (Steindachner, 1881). Aquaculture. 251: 509-515.

[6] Ghosal, M. \& Mandal, P. 2012. Phytochemical screening and antioxidant activities of two selected "Bihi" fruits used as vegetables in Darjeeling Himalaya. International Journal of Pharmacy and Pharmaceutical Sciences. 4(2): 567-574.

[7] Harborne, J. B. 1987. Metode Fitokimia: Penentuan Cara Modern Menganalisis Tumbuhan. (Padmawinata $\mathrm{K}$, penerjemah). Bandung: ITB.

[8] Vasic, S. M., Stefanovic, O. D., Licina, B. Z. Radojevic, I. D., \& Comic, L. R. 2012. Biological activities of extracts from cultivated Granadilla Passiflora alata. EXCLI Journal. 11: 208-218. 